\title{
The Implementation of Cooperative Integrated Reading and Composition (CIRC), Explicit Instruction, and Crossword Puzzle Models for Increasing the Indonesian Language Student Outcomes
}

\author{
Susilawati, Khairil Anwar \\ Faculty of Teacher Training and Education \\ Universitas Lambung Mangkurat \\ Banjarmasin, Indonesia \\ Susilawati.unlam@gmail.com
}

\begin{abstract}
The purpose of this study was to determine the activities of teachers, increase student activities and student learning the application of Cooperative Reading and Composition (CIRC), Explicit Instruction, and Crossword Puzzle models in the material identifying the elements. This study used a qualitative research approach to the type of action research. The subjects of this study were the class $V$ SDN Telawang 3 Banjarmasin in the even semester of 2017/2018. The research shows that Cooperative Integrated Reading and Composition (CIRC), Explicit Instruction dan Crossword Puzzle could increase concluded that the activity carried out by an excellent teacher , an increase in the activity of students to be very active, and student learning outcomes.
\end{abstract}

Keywords - Implementation, Cooperative Integrated Reading and Composition (CIRC), Explicit Instruction, Crossword Puzzle

\section{INTRODUCTION}

Clearly the objectives of national education derived from the Pancasila value system are formulated in Law No. 20 of 2003 Article 3, which formulates that national education has the function of developing capabilities and forming dignified national character and civilization in order to educate the nation's life, aiming at developing potential students to become human beings who believe and fear God the Almighty, noble, healthy, knowledgeable, capable, creative, independent, and a democratic and responsible citizen [1].

Preparation of a curriculum that is in accordance with the objectives to be achieved, it is necessary to increase teacher learning. Therefore, the first and foremost subsystem in improving the quality of education is the teacher factor. Quality education requires the availability of professional services for teachers and education staff. Thus, graduates of the future Indonesian society will have a strong character, respect cultural diversity as the glue of national integration, accompanied by mastery of the basics of life skills (soft skills) and the foundation of mastering science and technology needed for their duties as individuals in society, uphold ethical values and are responsible for the welfare of the nation and homeland [2]

According to reference [3], teachers who have good teaching performance are teachers who have several criteria or all of the above requirements on him, so that his teaching assignment is a noble task which will be carried out wholeheartedly, not half-heartedly.

Primary school students are expected to have good language skills because language is the most important capital for humans. So that individuals can use language in an interaction, they must have language skills. This ability is used to communicate messages in the form of ideas (ideas), desires, volition, feelings or interactions [3].

Based on the information obtained from the interview activities with the fifth-grade class teacher at SDN Telawang 3 Banjarmasin, some of the problems that exist in the subjects of Indonesian Language is especially the material that identifies the elements of the story. The information can be seen from the low learning outcomes of class $\mathrm{V}$ students in the 2016/2017 school year at SDN Telawang 3 Banjarmasin. Learning problems are the low learning outcomes obtained by students. With the Minimum Completion Criteria (KKM) school is 70. It can be seen from the data in 2016/2017 showing that out of 25 students only 8 students or $32 \%$ met the Minimum Completion Criteria (KKM), while 17 students or $68 \%$ had not met the Minimum Completion Criteria (KKM).

The causes of low student scores obtained based on the results of interviews conducted by researchers with class $\mathrm{V}$ guardian teachers at SDN Telawang 3 Banjarmasin are mistakes made by students themselves. It is because students are less directly involved in the learning process, less able to understand and digest the content of the story, and easily feel bored when the learning process takes place. This causes low student learning outcomes. 
If the problem is not resolved appropriately, it can be fatal, as evidenced by the presence of students who are not directly involved in the learning process, unable to understand and digest the contents of the story and easily feel bored when the learning process takes place. So that if this problem is left or not addressed then the value obtained by students will not reach KKM.

Based on the problems faced by the fifth-grade students of SDN above, the solutions that can be taken are applying the Cooperative Integrated Reading and Composition (CIRC) model, Explicit Instruction and Crossword Puzzle. With this Cooperative Integrated Reading and Composition (CIRC) learning model, students are expected to be directly involved in the learning process. Model Explicit Instruction can increase students 'understanding of reading or story, while in the Crossword Puzzle learning model can overcome students' boredom during learning.

Cooperative Integrated Reading and Composition (CIRC) is an integrated component of reading and writing in groups. The CIRC model is a special learning model for language subjects in order to read and discover the main ideas, main points, or themes of discourse [4].

Explicit Instruction specifically designed to develop student learning about knowledge of procedures and declarative knowledge that can be taught in a pattern step by step [4]. Crossword Puzzle is a learning model in the form of a crossword puzzle that can be used as a good and enjoyable learning strategy without losing the essence of ongoing learning. Even this strategy can involve active student participation from the beginning [5].

Several studies on the Cooperative Integrated Reading and Composition (CIRC) model, Explicit Instruction and Crossword Puzzles that have been carried out and can be used as studies in this study are researched from:

Research carried out by reference [6] and [7] using the Cooperative Integrated Reading And Composition (CIRC) model proved that teacher activity was carried out very well, student activities and learning outcomes increased. Likewise, research conducted by reference [8] and [9] by using the Explicit Instruction model proved that the teacher's activities were carried out very well, student activities and learning outcomes increased.

Research carried out by reference [10] using the Crossword Puzzle model proves that teacher activity is carried out very well, student activities and learning outcomes increase. Research conducted by reference [11] with the title Effects of Cooperative Integrated Reading and Composition (CIRC) Technique on Reading-Writing Skills at Primary School Students. The result shows that there is the influence of Cooperative Integrated Reading and Composition technique on writing skills and reading comprehension skills to the student.

\section{METHOD}

This study used a qualitative and quantitative approach. A qualitative approach is used to analyze teacher activities and student activities in learning while the quantitative approach is used to analyze learning outcomes data.

The type of research used in this study was Classroom Action Research (CAR). Classroom Action Research is an observation in the form of actions towards learning activities that are deliberately raised and occur in a class simultaneously [12].

Through PTK, teachers would gain more experience about the practice of learning effectively and not aimed at gaining new knowledge from the research of their actions. In other words, the main goal of CAR is to develop learning process skills, not to achieve general knowledge in the field of education [13].

This Classroom Action Research was conducted in class V of Telawang 3 Elementary School, in the second semester of the 2017/2018 school year. The number of students in class V was 25 people, consisting of 15 male students and 10 female students.

The reason the researchers did the research at the SDN was that there were problems, namely the difficulties in understanding Indonesian language lessons, especially the material identifying the elements of the story. this was evident from the results of interviews conducted by researchers before conducting research on fifth-grade students of SDN on the material identifying the elements of the story, from the Minimum Completion Criteria (KKM) set by the school was 70 , but there were still many students who score below KKM.

With the involvement of teachers in PTK, teachers can develop and improve their performance professionally, because teachers are able to assess, reflect on themselves, and be able to improve the learning they manage. In this case, the teacher is no longer just a practitioner who is satisfied with what has been done so far, but also as a researcher in their field who always wants to make innovative and creative learning improvements.

In addition to the elements of the teacher, learning also needs to pay attention to the elements of students. The need for student factors as the subject is observed because, it can be seen from the purpose of PTK, namely improving the quality of the learning process with the ultimate goal of improving student learning outcomes, so that PTK has enormous benefits in improving the quality of learning in the classroom.

With the implementation of CAR, mistakes and difficulties in the learning process (both strategies, techniques, concepts, etc.) will quickly be analyzed and diagnosed, so that errors and difficulties will not drag on. The activity of teachers in class V SDN on Indonesian language lessons material identifies the elements of the story can be said to be successful if it reaches a score of $\geq 30$ based on the observation table of teachers teaching with very good criteria.

Student activities in learning activities can be said to be successful if students who are in the active and very active category reach $\geq 82 \%$ with very active criteria. Individual completeness: individual students after the learning process takes place are said to have completed when students get a value of $\geq 70$. Classical completeness: students in classical are 
said to complete if $\geq 80 \%$ of the total students reach a value of $\geq 70$.

\section{RESULT AND DISCUSSION}

Based on the results of observations of teacher activities during the first cycle and second cycle of classroom action research it is known that there has been an improvement in teaching activities in conducting learning by applying a combination of Cooperative Integrated Reading and Composition models, Explicit Instruction and Crossword Puzzles.

TABLE I. RECAPITULATION OF TEACHERS' ACTIVITY

\begin{tabular}{|l|l|l|}
\hline \multicolumn{1}{|c|}{ Meeting } & \multicolumn{1}{|c|}{ Score } & \multicolumn{1}{c|}{ Criteria } \\
\hline 1 & $69,44 \%$ & Good \\
\hline 2 & $77,78 \%$ & Good \\
\hline 3 & $91,67 \%$ & Very Good \\
\hline 4 & $97,22 \%$ & Very Good \\
\hline
\end{tabular}

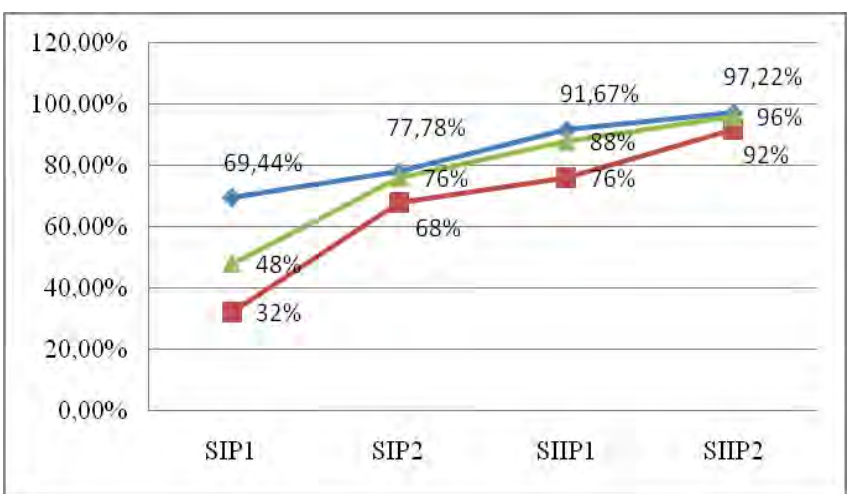

Fig. 1. The trend of the Teachers' Activity Increase, activities dan Students Learning Outcome

It can be said that teacher activity from cycle I to cycle II has increased, in the first cycle of meeting 1 teacher activity is $69.44 \%$ which is in the Good category and at the meeting 2 the teacher activity is $77.78 \%$ which is in the Good category than in the cycle II meeting 1 teacher activity is $91.67 \%$ which is in the Very Good category to $97.22 \%$ in the Excellent category in the second cycle of meeting 2 .

The results of individual student activities in each cycle with active and very active qualifications experienced an increase in the first cycle of meeting 1 only $32 \%$ with a fairly active category, while in the first cycle the meeting 2 reached $68 \%$ with the active category. In the second cycle the first meeting reached $76 \%$ with the active category and in the second cycle, the second meeting became $92 \%$ with the very active category.

Based on the learning outcomes of students in cycle I and the second cycle of applying the model of the Cooperative Integrated Reading and Composition, Explicit Instruction and Crossword Puzzle shows an increase in the completeness of student learning outcomes in cycle I and cycle II, namely in the first cycle of meetings 1 classically $48 \%$ and at the meeting 2 classically student learning outcomes were $76 \%$ then in the second cycle of meetings 1 classically student learning outcomes were $88 \%$ to $96 \%$ in the second cycle of meeting 2. This means that it can already be said to have reached a predetermined indicator namely students are considered complete learning if they have achieved classical completeness of at least $80 \%$.

The increase in teacher activity occurs because of the teacher's efforts in planning and implementing more maximal learning, and also the reflection that the teacher makes after the learning process so that future learning can run better. In addition, the teacher also always strives to improve the quality of learning in order to increase student activity in learning activities as a whole and can improve student learning outcomes.

The statement above is also in line with what is expressed by reference [14], in the learning process, the teacher does not only act as a model or role model for the students he teaches but also as a manager of learning. Thus, the effectiveness of the learning process lies with the teacher. Therefore, the success of a learning process is largely determined by the quality or ability of the teacher.

According to reference [15], the teacher also plays a role in providing learning facilities, so that the learning atmosphere is not monotonous and boring. With their creativity, teachers can overcome the limitations of the facilities so as not to hinder the atmosphere of learning in the classroom. Whereas according to reference [16], teachers must understand learning and learning strategies by implementing different learning and learning strategies in different situations and conditions.

The success of teacher activities, student activities, and learning outcomes in achieving the criteria of "Very Good," student learning outcomes reach the criteria of "Very Active," while learning outcomes reach "complete" criteria. The results of the increasing teacher, student and learning outcomes in the learning process with the application of Cooperative Integrated Reading And Composition (CIRC) models, Explicit Instruction and Crossword Puzzles are supported by relevant research results by other researchers, such as:

Research conducted by [6] [7], using the Cooperative Integrated Reading And Composition model proved that teacher activity could be carried out very well. Research conducted by reference [8] [9] using the Explicit Instruction model proved that teacher activity could be carried out very well. Research conducted by reference [10], using the Crossword Puzzle model proved that teacher activity could be carried out very well.

Students are no longer used as silent objects whose job is only to listen to the material delivered by the teacher. But as a whole, the subject itself is actively involved in the organization and discovery of information (knowledge) so that they not only passively accept the knowledge given by the teacher.

The above is in line with the opinion of reference [17], learning will be more meaningful if students are given the opportunity to participate in various learning activities so that students are able to actualize their abilities inside and outside the classroom. Furthermore, reference [16] argues that the activity of students in the learning process can stimulate and 
develop their talents. Students can also practice to think critically and be able to solve problems in everyday life. Besides that, the teacher can also engineer a learning system systematically to stimulate participant activity in the learning process.

Through well-planned evaluation actions, the data obtained can be more accurate. This is because the item items generated refer to the aspects of the desired learning outcomes according to the intended learning goals. As stated by reference [18], evaluation is part of teacher activities that cannot be ignored because evaluation can provide clues to where the success of the learning process activities that have been carried out. Evaluation is not just carried out so that items are made that seem careless. Evaluation is expected to provide accurate data, so as to be able to provide accurate data, be followed up by programming better learning activities.

According to reference [6], the activity of learning experienced by students relates to all activities that occur, both physically and non-physically. Activeness will create a teaching and learning situation that emphasizes the activity of students, both physically, mentally, intellectually and emotionally to obtain learning outcomes in the form of a combination of cognitive, affective, and psychomotor aspects. Active learning is needed by students to get optimal learning outcomes.

In addition to the above explanation, increasing student learning outcomes in the learning process with the application of Cooperative Integrated Reading And Composition (CIRC) models, Explicit Instruction and Crossword Puzzle is also supported by the results of relevant research by researchers supporting researchers above, that learning outcomes increase in accordance with predetermined indicators.

The results of the research findings and discussion concluded that teacher activities, student activities, and learning outcomes were carried out in accordance with expectations, with very good criteria. Student activity has increased until it reaches very active criteria and student learning outcomes can increase according to the indicators of success determined by the researcher.

Based on all that has been described above, suggestions can be made to interested parties in the research. These suggestions are to the principal, the results of this study can be an alternative input in fostering the teachers in the school they lead in order to improve the quality of the process and learning outcomes. For teachers, the results of this study can be used as one of the references in the selection of learning models in order to improve learning outcomes and foster student motivation. For this research, the student can improve and fulfill the KKM. And increasing students' understanding of the material identifies the elements that exist in the story through the use of the model applied by the author. For other researchers, the results of this study can be used as reference material in generating innovative combinations of other learning models so that they can improve the quality of learning and student learning outcomes, especially in elementary schools.

\section{CONCLUSION}

Based on the findings of the research and discussion, the conclusion is that the teacher's activities carry out language skills learning in identifying the elements of the story with the application of the Cooperative Integrated Reading and Composition (CIRC) model, Explicit Instruction and Crossword Puzzle in class V Telawang 3 Banjarmasin SDN implemented according to expectations, with very good criteria. Student activity has increased until it reaches very active criteria and student learning outcomes can increase according to the indicators of success determined by the researcher.

From the above explanation, it can be suggested that:

- For the Headmaster. The results of this study can be an alternative input in fostering teachers in the schools they lead in order to improve the quality of learning processes and outcomes.

- For the Teachers. The results of this study can be used as a reference in the selection of learning models in order to improve learning outcomes and foster student motivation.

- For the Next Researchers. The results of this study can be used as reference material in generating innovations in combination with other learning models so as to improve the quality of learning and student learning outcomes, especially in elementary school.

\section{REFERENCES}

[1] W. Sanjaya, Strategi pembelajaran. Jakarta: Kencana, 2014.

[2] A. Suriansyah, and Aslamiah, "Strategi kepemimpinan kepala sekolah, guru, orang tua, dan masyarakat dalam membentuk karakter Siswa," [Online], $2015 . \quad$ Available: http://journal.uny.ac.id/index.php/cp/article/view/4828, [Accessed 31 Jul 2018].

[3] A. Susanto, Teori belajar dan pembelajar. Jakarta: PT. Fajar Interpratama Mandiri, 2014.

[4] A. Shoimin, 68 Model pembelajaran inovatif dalam kurikulum 2013. Yogyakarta: Ar-Ruzz Media, 2016.

[5] H. Zaini, B. Munthe, and S. A. Aryani, Strategi pembelajaran aktif. Yogyakarta: Pustaka Insane Madani, 2008.

[6] E. R. Linda, "Meningkatkan hasil belajar membaca intensif pada materi menentukan ide pokok melalui model cooperative integrated reading and composition dan course review horay siswa kelas IV SDN 4 Loktabat Utara Banjarbaru," unpublished.

[7] N. Rahmah, "Meningkatkan keterampilan membaca pemahaman dalam menentukan kalimat utama pada satuan paragraf menggunakan model pembelajaran cooperative integrated reading and composition (CIRC) Siswa Kelas 4 SDN Benua Anyar 3 Banjarmasin," unpublished.

[8] N. Aslimah, "Meningkatkan keterampilan menulis karangan deskripsi menggunakan model think pair and share (TPS) Divariasi Explicit Instruction Siswa Kelas IV SDN Lokpaikat 3 Kabupaten Tapin," unpublished.

[9] S. Santi, "Meningkatkan hasil belajar jaring-jaring bangun ruang melalui model explicit instruction dan numbered head together (NHT) siswa kelas V SDN Tanjung Rema Martapura," unpublished.

[10] A. Rokhim, "Meningkatkan hasil belajar siswa pada materi keputusan bersama melalui pendekatan kooperatif tipe crossword puzzle pada kelas V SDN Alalak Utara 2 Banjarmasin", unpublished.

[11] E. Durukan, "Effects of Cooperative Integrated Reading and Composition (CIRC) Technique on Reading-Writing Skills," [Online]. 
Available: http://www.academicjournals.org/journal/ERR/article-fulltext-pdf/E3C56E94418, [Accessed: 20 Jul 2018].

[12] S. Suyadi, Panduan penelitian tindakan kelas, Yogyakarta: Diva Pers, 2010

[13] M. Mulyasa, Praktik penelitian tindakan kelas, Bandung: PT Remaja Rosdakarya, 2017.

[14] A. Suriansyah and N. Aslamiah, strategi pembelajaran, Jakarta: PT. RajaGrafindo Perasada, 2014.

[15] I. Isjoni, Pembelajaran kooperatif meningkatkan kecerdasan komunikasi antara peserta didik, Yogyakarta: Pustaka Pelajar, 2012.

[16] D. J. Priansa, Pengembangan strategi dan model pembelajaran, Bandung: CV. Redaksi Pustaka Setia, 2017.

[17] R. Rusman, Model-Model pembelajaran mengembangkan Profesionalisme Guru, Jakarta: Rajawali Pers, 2014.

[18] A. Suriansyah and N. Aslamiah, Profesi kependidikan, Jakarta: Raja Grafindo Persada, 2014 